BIOMEDICAL AND BIOSOCIAL ANTHROPOLOGY
$\begin{gathered}\text { Official Journal of the International Academy } \\ \text { of Integrative Anthropology } \\ \text { journal homepage: http://bba-journal.com }\end{gathered}$

\title{
Component composition of body weight in patients with non- alcoholic fatty liver disease
}

\section{Pivtorak K.V.}

National Pirogov Memorial Medical University, Vinnytsya, Ukraine

\section{ARTICLE INFO}

Received: 11 March 2019

Accepted: 18 April 2019

UDC: $616.36-003.826: 616-$

071.3:572.087

\section{CORRESPONDING AUTHOR}

e-mail: ek3727@gmail.com Pivtorak K.V.
The issue of the relationship between the features of the component composition of body weight with the emergence and development of non-alcoholic fatty liver disease (NAFLD) is particularly relevant. The purpose of the study is to determine the features of the component composition of the body weight in patients with NAFLD compared with almost healthy people of the first mature age. A comprehensive examination and analysis of anthropometric data of 112 patients with NAFLD of the first mature age of the Podolski region was carried out in comparison with the anthropometric data of practically healthy people, which were taken from the data bank of the materials of the research center of National Pirogov Memorial Medical University. The necessary anthropometric parameters for determining the absolute amount of adipose tissue, the absolute amount of muscle tissue, the absolute amount of bone component in body weight, using the formulas of J. Matiegka. Statistical analysis of the obtained results was performed in the program "STATISTICA 8" using parametric and non-parametric methods of estimation of the obtained results. It was found that the body fat according to the Matiegka formula in men and women with NAFLD was statistically significantly higher $(p<0.001)$ than in the same sex of healthy men and women. Muscle weight and bone mass calculated by the Matiegka formula in men and women with NAFLD were statistically significantly lower $(p<0.05)$ than in the healthy sex of men and women. Moreover, muscle and bone mass in healthy and NAFLD men were statistically significantly greater $(p<0.05)$ than in the same age groups of women. Men and women with NAFLD have strong inverse correlations between muscle mass and body mass index. Also, the mean strengths of the correlation between the bone mass and body mass index were established. The obtained results, together with a known increase in body fat in NAFLD, show a significant change in muscle and bone mass toward a decrease, which allows us to identify new potential therapeutic targets.

Keywords: non-alcoholic fatty liver disease, anthropometry, component composition of body weight, correlation relationships.

\section{Introduction}

Nonalcoholic fatty liver disease (NAFLD) is now recognized as the most common chronic liver disease worldwide [29]. Currently NAFLD is considered a multifactorial disease. Along with the prevalence of obesity, the number of patients with non-alcoholic fatty liver disease is increasing. Nonalcoholic steatohepatitis (NASH) is common in patients with obesity, insulin resistance, type 2 diabetes, and increases the risk of hepatocellular carcinoma [16]. Most often, NAFLD is found in individuals who, in addition to a high body mass index and obesity, have observed a decrease in muscle mass [10]. An increase in fat mass and decrease in muscle mass leads to an increase in metabolic disorders [15]. Muscle peptides and cytokines released from muscle are also thought to have endocrine and paracrine action [19]. Thus, reducing muscle mass not only affects physical function, the loss of muscle mass can directly affect other physiological systems in the body and vice versa.

Recently, it was hypothesized that in case of NAFLD leptin increases muscle catabolism, which leads to a decrease in physical activity, which through a vicious circle leads to an increase in fat accumulation and weight gain [14].

Recent studies have shown [2] that skeletal muscles and bones act as endocrine organs. The interconnection of bones, muscles and adipose tissue is increasingly manifested by the increased prevalence of sarcopenia and osteoporosis in chronic conditions such as diabetes, 
metabolic syndrome and obesity [3].

Sarcopenia is an atrophic degenerative condition of skeletal muscle, which leads to a loss of their strength and volume [18]. It is established that sarcopenia is a frequent complication in cirrhosis, which negatively affects the prognosis of the disease $[5,13]$. In the scientific literature it is noted $[6,9]$ that the muscular body weight of practically healthy men is statistically significantly larger $(p<0.001)$ than in men with chronic viral hepatitis B or C.

At present, there is no unambiguous opinion as to whether or not NAFLD leads to sarcopenia through the activation of myostatin in skeletal muscle, or if sarcopenia is the primary anomaly leading to activation of stellate cells in the liver [27]. Given the hypothesis that myostatin increases adipose tissue mass, leading to decreased adiponectin secretion, the initial defect may actually begin in skeletal muscle [17].

Interaction between muscles and bones includes bonederived osteokines, muscle myokines and cytokines of dual origin that trigger common signaling pathways leading to fibrosis, inflammation, or protein synthesis or degradation [21].

That is, if bone cells secrete less "osteokines" and skeletal muscles secrete fewer myokines, fat metabolism and renal function may be impaired, even testosterone levels, which are expressed in the function of many organs, which are commonly interpreted as "the effects of aging" [4]. This new perspective prompts a new revision of the pathogenesis of NAFLD.

Thus, today the question of the connection of the features of the component composition of body weight with the emergence and development of non-alcoholic fatty liver disease is especially urgent.

The purpose of the study is to determine the features of the component composition of the body weight in patients with non-alcoholic fatty liver disease in comparison with almost healthy people of the first mature age.

\section{Materials and methods}

A comprehensive examination of 112 patients with nonalcoholic fatty liver disease (NAFLD) was performed. Informed consent to the use of materials in scientific research was accepted from each patient examined.

All studies were performed in accordance with the basic provisions of the GSR (1996), the Council of Europe Convention on Human Rights and Biomedicine (dated 04.04.1997), the Helsinki Declaration of World Health Association on Ethical Principles for the Conduct of Scientific Medical Research with human participation (1964-2013), the order of the Ministry of Health of Ukraine No. 690 dated September 23, 2009, No. 616 dated August 3, 2012.

To determine the diagnostic criteria for NAFLD, we analyzed the anthropometric data of men and women of the first mature age of the Podylskyi region, patients with NAFLD, and compared them with the anthropometric data of practically healthy people. As a control, the primary indicators of anthropometric and somato-typological studies of practically healthy urban men and women of Podillia of a similar age were taken from a data bank of materials from the research center of Vinnitsa National Pirogov Memorial Medical University. The control group consisted of 225 healthy people.

All patients included in the clinical trial were thoroughly examined. The examination system included both general clinical and special examination methods

The diagnosis of NAFLD was established on the basis of the unified clinical protocol of primary and secondary (specialized) medical care "Non-alcoholic steatohepatitis", approved by the order of the Ministry of Health of Ukraine No. 826 dated 6.11.2014 and clinical recommendations of EASLEASD-EASO on diagnosis and treatment of NAFLD [8].

J. Matiegka's formulas [12] were used to determine the component composition of body weight. The corresponding constants were used.

To determine the absolute amount of adipose tissue in body weight in patients with NAFLD, men and women determined the surface area of the body in Du Bois calculation [12] $\left(\mathrm{m}^{2}\right)$, body weight $(\mathrm{kg})$, body length $(\mathrm{cm})$, measured using caliper skin thickness - fatty folds $(\mathrm{mm})$ on the shoulders, forearms, back, abdomen, thighs, lower legs, under the shoulder blade and additionally only in men the thickness of the skin-fat folds on the chest.

To determine the absolute amount of muscle tissue in body weight in patients with NAFLD men and women determined the length of the body $(\mathrm{cm})$, radii of the shoulder, forearm, hips, lower leg at the sites of greatest development of the muscles by measuring a circle equal to $2 \mathrm{r}$ (except skin-fat layer) $(\mathrm{cm})$.

To determine the absolute amount of bone component in body weight in patients with NAFLD men and women determined the length of the body $(\mathrm{cm})$, the diameters of the distal parts of the shoulder, forearms, hips and lower legs (cm).

\section{Results}

The results of the survey showed that the mass and surface area of the body in men with NAFLD were statistically significantly greater than in healthy men $(p<0.001)$ and patients with NAFLD $(p<0.05)$, and the weight and surface area of the body in in patients with NAFLD, women were statistically significantly larger $(p<0.001)$ than in healthy women.

The thickness of the skin and fat folds on the front and back surfaces of the shoulder, forearm, back, abdomen, thighs, lower leg, under the scapula in men and women with NAFLD, were statistically significantly greater than in healthy men and healthy women, respectively $(p<0.001)$. The thickness of skin and fat folds on breasts in healthy men was statistically significantly smaller $(p<0.001)$ than in patients with NAFLD.

We determined that the average radius of the shoulder, forearm, thigh, shin in areas of greatest muscular 
development (except for the skin and fat layer) was statistically significantly smaller $(p<0.05)$ in men and women with NAFLD than in the corresponding by gender of men and women.

The diameters of the distal parts of the shoulder, forearm, thigh, and lower leg were significantly smaller in patients with NAFLD $(p<0.05)$ than in healthy men; and women with NAFLD were statistically significantly less $(p<0.05)$ than healthy women. Moreover, the diameters of the distal parts of the shoulder, forearm, thigh and lower leg in healthy and patients with NAFLD men were statistically significantly greater $(p<0.05)$ than in the respective groups of women.

It was found that the fat mass according to J. Matiegka in men and women suffering from NAFLD was statistically significantly higher $(p<0.001)$ than in the corresponding sex of healthy men and women (Fig. 1).

Muscle body mass, determined by the Matiegka formula in men and women with NAFLD, was found to be statistically significantly lower $(p<0.05)$ than in those of healthy men and women (Fig. 2). Moreover, the muscle mass in healthy and

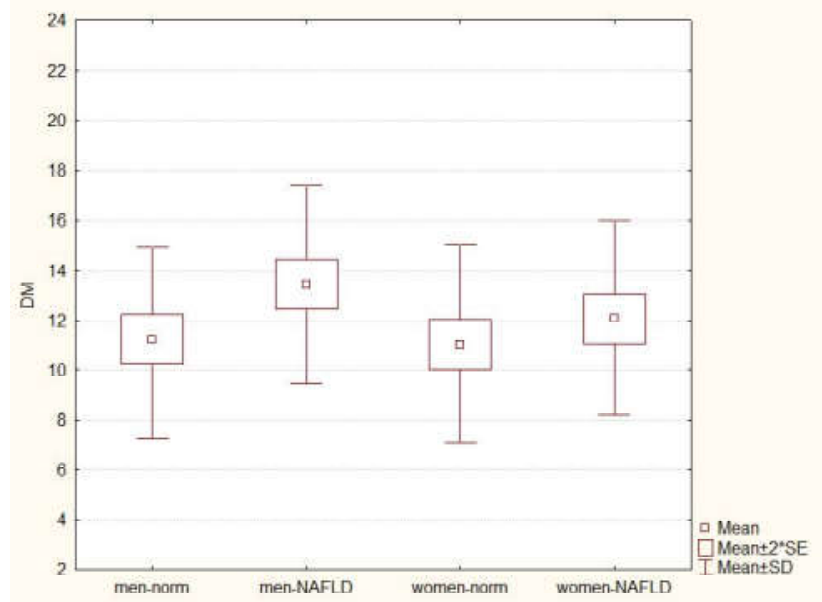

Fig. 1. Indicators of body fat according to Matiegka's method in healthy and patients with NAFLD men and women $(\mathrm{kg})$.

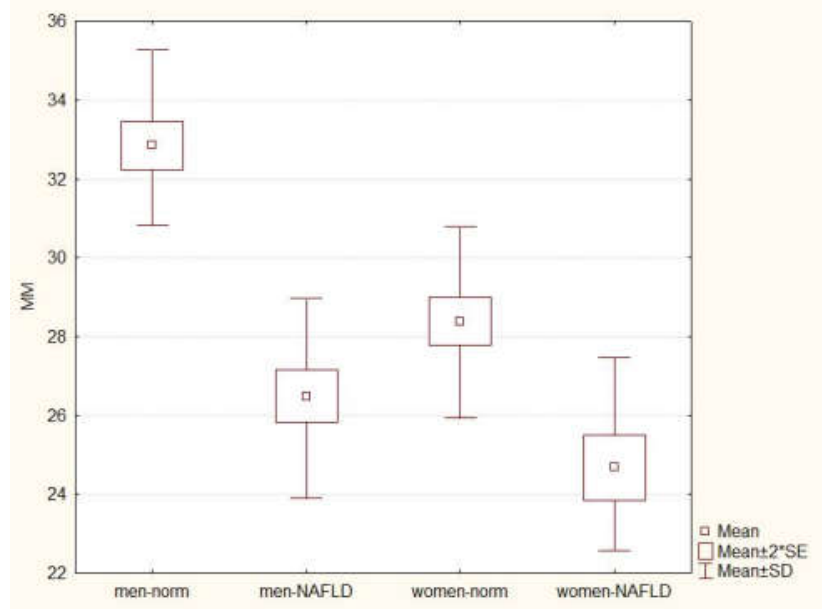

Fig. 2. Muscle body weight according to the Matiegka's formula in healthy and NAFLD patients men and women.

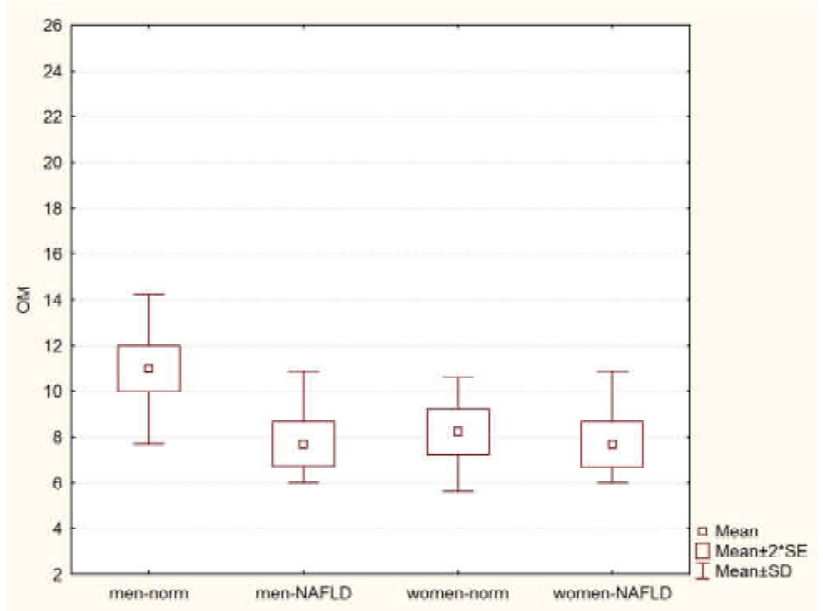

Fig. 3. Indicators of bone mass by the method of Matiegka in healthy people and patients with NAFLD men and women.

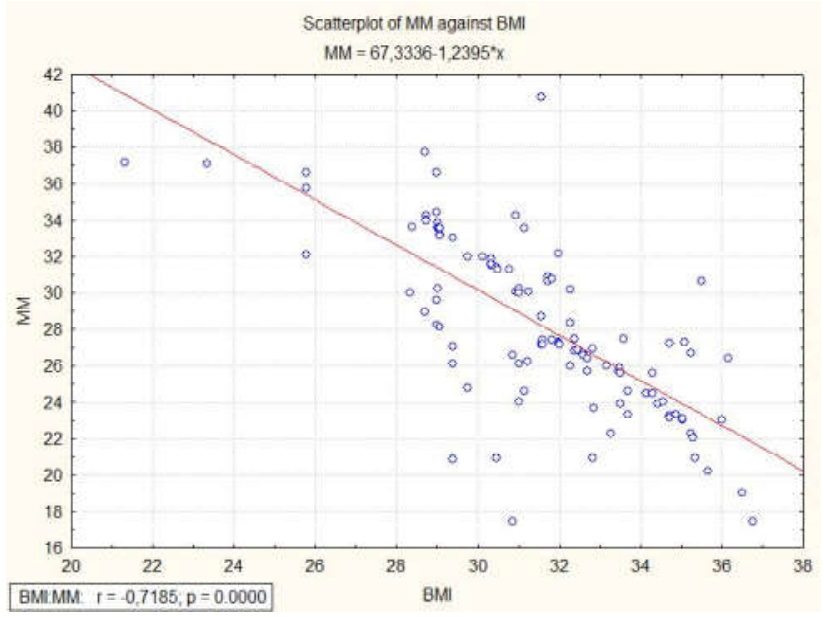

Fig. 4. Relationship between the indicators of muscle mass according to J.Matiegka and body mass index of patients with NAFLD.

men with NAFLD was statistically significantly greater $(p<0.05)$ than in the corresponding groups of women.

Bone body mass according to the J. Matiegka method in men with NAFLD was statistically significantly lower than in healthy $(p<0.05)$ men (Fig. 3). Bone body mass, according to the Matiegka formula, was statistically significantly higher $(p<0.05)$ in healthy and NAFLD men than in the corresponding groups of women.

According to the results of the study, the component composition of body weight in NAFLD changes. Compared to healthy men with NAFLD, men's fat mass was $16.4 \%$ higher for men, while men's muscle mass and bone mass were $19.3 \%$ and $29.9 \%$ lower for men, respectively.

Compared with healthy women with NAFLD, the fat body weight of the Matiegka formula was $8.6 \%$ higher, while the muscle and bone mass of the Matiegka women were $13.1 \%$ and $6.5 \%$, respectively. $\%$ respectively.

Strong inverse correlations were established between the muscular body mass according to the Matiegka's method and the body mass index in men and women with NAFLD 


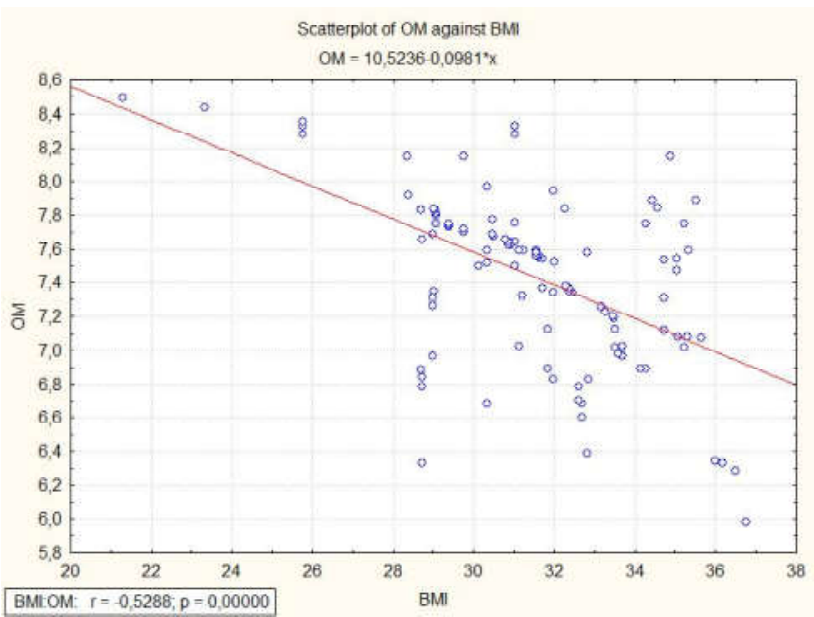

Fig. 5. Relationship between bone mass indices by Matiegka and body mass index of patients with NAFLD.

(Fig. 4).

Between the bone mass according to Matiegka and the body mass index in men and women with NAFLD, inverse mean strength correlations were established (Fig. 5).

\section{Discussion}

It is believed that quantitative assessment of muscle mass by measurements in one anatomical area, such as limb muscles or abdominal cavity, provides a fairly accurate measurement of whole body muscle mass [25]. By us [22], by means of discriminant analysis, among all anthropometric measurements, we found the main indicators that carry the greatest information about the presence of non-alcoholic fatty liver disease in persons of the first mature age. Among them were men's index of body mass index and muscle mass according to the formula Matiegka. Recent studies have shown that sarcopenia and NAFLD have similar pathophysiological characteristics [30].

Sarcopenic obesity, in combination with progressive loss of skeletal muscle mass, adversely affects human metabolic status, leading to a decrease in quality of life and development of cardiovascular disease [1].

A number of researchers $[20,26]$ have described the negative effects of sarcopenia in cirrhosis. The skeletal muscles contain the main protein supply in the human body. Scientists have linked the development of sarcopenia in cirrhosis with impaired urea cycle activity, which begins in the matrix of liver mitochondria, leading to hyperammonemia

\section{References}

[1]Bhanji, R. A., Narayanan, P., Allen, A. M., Malhi, H., \& Watt, K. D. (2017). Sarcopenia in hiding: the risk and consequence of underestimating muscle dysfunction in nonalcoholic steatohepatitis. Hepatology, 66(6), 2055-2065. https://doi.org/ 10.1002/hep.29420

[2] Brotto, M., \& Bonewald, L. (2015). Bone and muscle: interactions beyond mechanical. Bone, 80, 109-114. doi: 10.1016/ j.bone.2015.02.010

[3] Brotto, M., \& Johnson, M. L. (2014). Endocrine crosstalk between muscle and bone. Current osteoporosis reports, 12(2), 135-
[7].

The pathogenesis of sarcopenia and NAFLD has common mechanisms: insulin resistance, increased inflammation, skeletal muscle secretion, myostatin, decreased adiponectin, vitamin $\mathrm{D}$ deficiency, and lack of physical activity $[11,17]$.

The pathogenesis of sarcopenia and NAFLD has common mechanisms: insulin resistance, increased inflammation, secretion of myokines, myostatin by skeletal muscle, decreased adiponectin level, vitamin D deficiency, and lack of physical activity $[11,17]$.

Skeletal muscle mass maintains a balance between protein synthesis, regenerative ability and regulation of skeletal muscle function. The current understanding of the pathogenesis of sarcopenia in cirrhosis is associated with metabolic kinetics and molecular signaling pathways [23, 24, 28].

Our results, along with a known increase in the fat component of the NAFLD patient's body mass, show a significant decrease in muscle and bone mass, which allows us to outline new potential therapeutic targets.

Conclusions and prospects for further research.

It was found that the body mass according to the formula Matiegka in men and women with NAFLD was statistically significantly higher than in the corresponding gender of healthy men and women.

The body mass, according to the Matiegka's method, of men and women with NAFLD was statistically significantly less than that one of healthy men and women.

Bone body mass according to the J.Matiegka's formula in men with NAFLD is statistically significantly less than in healthy men.

In the future it is planned to investigate the correlation relationships of anthropometric parameters of the body, the component body weight with hormonal changes in the body of patients with NAFLD.

\section{Gratitude}

The author is grateful to the Research Center of National Pirogov Memorial Medical University for the opportunity to use the data bank of the center of anthropometric and somato-typological researches of practically healthy urban men and women of Podillya in carrying out the analysis of this research.

141. doi: 10.1007 / s11914-014-0209-0

[4] Carson, J. A., \& Manolagas, S. C. (2015). Effects of sex steroids on bones and muscles: Similarities, parallels, and putative interactions in health and disease. Bone, 80, 67-78. doi: 10.1016/j.bone.2015.04.015.

[5] Dasarathy, S., \& Merli, M. (2016). Sarcopenia from mechanism to diagnosis and treatment in liver disease. Journal of hepatology, 65(6), 1232-1244. doi: https://doi.org/10.1016/ j.jhep.2016.07.040

[6] Datsenko, G. V., Moroz, L. V., Gunas, I. V., \& Dugelny, A. G. 
(2009). Comprehensive body size in healthy and chronic B and $C$ viral hepatitis patients in urban men and women in Podillya. Biomedical and Biosocial anthropology, 13, 129-134.

[7] Davuluri, G., Krokowski, D., Guan, B. J., Kumar, A., Thapaliya, S., Singh, D., ... \& Dasarathy, S. (2016). Metabolic adaptation of skeletal muscle to hyperammonemia drives the beneficial effects of I-leucine in cirrhosis. Journal of hepatology, 65(5), 929-937. doi: 10.1016/j.jhep.2016.06.004

[8] European Association for the Study of the Liver, \& European Association for the Study of Diabetes (EASD. (2016). EASLEASD-EASO Clinical Practice Guidelines for the management of non-alcoholic fatty liver disease. Journal of Hepatology, 64(6), 1388-1402. doi: https://doi.org/10.1016/ j.jhep.2015.11.004

[9] Gunas, I. V., Dugelnyi, A. G., Prokopenko, S. V., \& Datsenko, G. V. (2009). Somatotype and component composition of body weight in healthy and patients with chronic viral hepatitis "B" or "C" of urban men and women in Podillya. Reports of Morphology, 15(2), 391-396.

[10] Hong, H. C., Hwang, S. Y., Choi, H. Y., Yoo, H. J., Seo, J. A., Kim, S. G., ... \& Choi, K. M. (2014). Relationship between sarcopenia and nonalcoholic fatty liver disease: the Korean Sarcopenic Obesity Study. Hepatology, 59(5), 1772-1778. https://doi.org/10.1002/hep.26716

[11] Koo, B. K., Kim, D., Joo, S. K., Kim, J. H., Chang, M. S., Kim, B. G., ... \& Kim, W. (2017). Sarcopenia is an independent risk factor for non-alcoholic steatohepatitis and significant fibrosis. Journal of hepatology, 66(1), 123-131. doi: 10.1016/ j.jhep.2016.08.019.

[12] Koveshnikov, V.G., \& Nikityuk, B.A. (1992). Medical anthropology. K.: Health's.

[13] Kremer, W. M., Koch, S., Lochner, D., Koch, A. C., Hahn, F., Grambihler, A., ... \& Weinmann, A. (2019). SAT-067-Prospective assessment of sarcopenia as a prognostic factor for survival in patients with liver cirrhosis. Journal of Hepatology, 70(1), e656-e657. doi: https://doi.org/10.1016/S06188278(19)31309-X

[14] Lee, Y. H., Jung, K. S., Kim, S. U., Yoon, H. J., Yun, Y. J., Lee, B. W., ... \& Cha, B. S. (2015). Sarcopaenia is associated with NAFLD independently of obesity and insulin resistance: Nationwide surveys (KNHANES 2008-2011). Journal of hepatology, 63(2), 486-493. doi: https://doi.org/10.1016/ j.jhep.2015.02.051

[15] Lim, S., Kim, J. H., Yoon, J. W., Kang, S. M., Choi, S. H., Park, Y. J., ... \& Jang, H. C. (2010). Sarcopenic obesity: prevalence and association with metabolic syndrome in the Korean Longitudinal Study on Health and Aging (KLoSHA). Diabetes care, 33(7), 1652-1654. https://doi.org/10.2337/dc10-0107

[16] Mantovani, A., \& Targher, G. (2017). Type 2 diabetes mellitus and risk of hepatocellular carcinoma: spotlight on nonalcoholic fatty liver disease. Annals of translational medicine, 5(13), 270. doi: 10.21037/atm.2017.04.41

[17] Merli, M., \& Dasarathy, S. (2015). Sarcopenia in non-alcoholic fatty liver disease: Targeting the real culprit? Journal of hepatology, 63(2), 309-311. doi: https://doi.org/10.1016/ j.jhep.2015.05.014

[18] Misnikova, I.V., Kovaleva, Yu.A., \& Klimina, N.A. (2017). Sarcopenic obesity. Russian Medical Journal, 25(1), 24-29.
[19] Pedersen, B. K., \& Febbraio, M. A. (2008). Muscle as an endocrine organ: focus on muscle-derived interleukin-6. Physiological reviews, 88(4), 1379-1406. doi:10.1152/ physrev.90100.2007

[20] Periyalwar, P., \& Dasarathy, S. (2012). Malnutrition in cirrhosis: contribution and consequences of sarcopenia on metabolic and clinical responses. Clinics in liver disease, 16(1), 95131. doi: 10.1016/j.cld.2011.12.009

[21] Piette, A. B., Hamoudi, D., Marcadet, L., Morin, F., Argaw, A., Ward, L., \& Frenette, J. (2018). Targeting the muscle-bone unit: filling two needs with one deed in the treatment of Duchenne muscular dystrophy. Current osteoporosis reports, 16(5), 541-553. doi: 10.1007/s11914-018-0468-2

[22] Pivtorak, K. V. (2017). Anthropometric studies of patients with nonalcoholic fatty liver disease. Zaporozhye Medical Journal, 19(5), 623-628. doi: https://doi.org/10.14739/23101210.2017.5.110169

[23] Qiu, J., Thapaliya, S., Runkana, A., Yang, Y., Tsien, C., Mohan, M. L., ... \& Stark, G. R. (2013). Hyperammonemia in cirrhosis induces transcriptional regulation of myostatin by an NF-?Bmediated mechanism. Proceedings of the National Academy of Sciences, 110(45), 18162-18167. https://doi.org/10.1073/ pnas. 1317049110

[24] Qiu, J., Tsien, C., Thapalaya, S., Narayanan, A., Weihl, C. C., Ching, J. K., ... \& McDonald, C. (2012). Hyperammonemiamediated autophagy in skeletal muscle contributes to sarcopenia of cirrhosis. American Journal of PhysiologyEndocrinology and Metabolism, 303(8), E983-E993. doi: 10.1152/ajpendo.00183.2012

[25] Shen, W., Punyanitya, M., Wang, Z., Gallagher, D., St.-Onge, M. P., Albu, J., ... \& Heshka, S. (2004). Total body skeletal muscle and adipose tissue volumes: estimation from a single abdominal cross-sectional image. Journal of applied physiology, 97(6), 2333-2338. doi: 10.1152/ japplphysiol.00744.2004

[26] Tandon, P., Ney, M., Irwin, I., Ma, M. M., Gramlich, L., Bain, V. G., ... \& Myers, R. P. (2012). Severe muscle depletion in patients on the liver transplant wait list: its prevalence and independent prognostic value. Liver Transplantation, 18(10), 1209-1216. https://doi.org/10.1002/lt.23495

[27] Tovo, C. V., Fernandes, S. A., Buss, C., \& de Mattos, A. A. (2017). Sarcopenia and non-alcoholic fatty liver disease: Is there a relationship? A systematic review. World journal of hepatology, 9(6), 326. doi: 10.4254/wjh.v9.i6.326

[28] Tsien, C., Davuluri, G., Singh, D., Allawy, A., Ten Have, G. A., Thapaliya, S., ... \& Deutz, N. E. (2015). Metabolic and molecular responses to leucine?enriched branched chain amino acid supplementation in the skeletal muscle of alcoholic cirrhosis. Hepatology, 61(6), 2018-2029. https://doi.org/10.1002/ hep. 27717

[29] Younossi, Z., Anstee, Q. M., Marietti, M., Hardy, T., Henry, L., Eslam, M., ... \& Bugianesi, E. (2018). Global burden of NAFLD and NASH: trends, predictions, risk factors and prevention. Nature reviews Gastroenterology \& hepatology, 15(1), 11-20. doi:10.1038/nrgastro.2017.109

[30] Zhai, Y., \& Xiao, Q. (2017). The common mechanisms of sarcopenia and NAFLD. BioMed research international, Published online 2017. doi: 10.1155/2017/6297651

\section{КОМПОНЕНТНИЙ СКЛАД МАСИ ТІЛА У ХВОРИХ НА НЕАЛКОГОЛЬНУ ЖИРОВУ ХВОРОБУ ПЕЧІНКИ}

\section{Півторак К.В.}

Питання зв'язку особливостей компонентного складу маси тіла з виникненням і розвитком неалкогольної жирової хвороби печінки (НАЖХП) являється особливо актуальним. Мета дослідження - встановити особливості компонентного складу маси тіла у хворих на НАЖХП у порівнянні з практично здоровими людьми першого зрілого віку. Проведені комплексне 
обстеження та аналіз антропометричних даних 112 хворих на НАЖХП першого зрілого віку Подільського регіону та порівняно їх з антропометричними даними практично здорових людей, що були взяті з банку даних матеріалів науково-дослідного центру Вінницького національного медичного університету ім. М.І. Пирогова. Визначено необхідні антропометричні показники для встановлення абсолютної кількості жирової тканини, абсолютної кількості м'язової тканини, абсолютної кількості кісткового компонента у масі тіла, застосовуючи фоорули J. Matiegka. Cтатистичний аналіз отриманих результатів проведений у програмі "STATISTICA 8" з використанням параметричних і непараметричних методів оцінки отриманих результатів. Встановлено, що жирова маса тіла за Матейко у чоловіків і жінок, хворих на НАЖХП, була статистично значуще більша $(p<0,001)$, ніж у відповідних за статтю здорових чоловіків і жінок. М'язова маса та кісткова маса тіла за Матейко у чоловіків $і$ жінок, хворих на НАЖХП, виявилася статистично значуще меншою (p<0,05), ніж у відповідних за статтю здорових чоловіків і жінок. Причому, м'язова та кісткова маса тіла у здорових і хворих на НАЖХП чоловіків статистично значуще більші (p<0,05), ніж у відповідних груп жінок. У чоловіків і жінок, хворих на НАЖХП, встановлені зворотні сильні кореляційні зв'язки між м'язовою масою тіла за Матейко та індексом маси тіла. Також встановлені зворотні середньої сили кореляційні зв'язки між кістковою масою тіла за Матейко та індексом маси тіла. Отримані нами результати, наряду з відомим збільшенням жирової маси тіла при НАЖХП, показали значну зміну м'язової та кісткової маси тіла в сторону зменшення, що дозволяє намітити нові потенційні терапевтичні мішені.

Ключові слова: неалкогольна жирова хвороба печінки, антропометрія, компонентний склад маси тіла, кореляційні зв'язки.

\section{КОМПОНЕНТНЫЙ СОСТАВ МАССЫ ТЕЛА У БОЛЬНЫХ НЕАЛКОГОЛЬНОЙ ЖИРОВОЙ БОЛЕЗНЬЮ ПЕЧЕНИ \\ Пивторак Е.В.}

Вопросы связи особенностей компонентного состава массы тела с возникновением и развитием неалкогольной жировой болезни печени (НАЖБП) является особенно актуальным. Цель исследования - установить особенности компонентного состава массы тела у больных НАЖБП по сравнению с практически здоровыми людьми первого зрелого возраста. Проведено комплексное обследование и анализ антропометрических данных 112 больных НАЖБП первого зрелого возраста Подольского региона сравнительно с антропометрическими данными практически здоровых людей, которые были взяты из банка данных материалов научно-исследовательского центра Винницкого национального медицинского университета им. Н.И. Пирогова. Определены необходимые антропометрические показатели для установления абсолютного количества жировой ткани, абсолютного количества мышечной ткани, абсолютного количества костного компонента в массе тела, применяя формулы J. Matiegka. Cтатистический анализ полученных результатов проведен в программе "STATISTICA 8" c использованием параметрических и непараметрических методов оценки полученных результатов. Установлено, что жировая масса тела по Матейко у мужчин и женщин, больных НАЖБП, была статистически значимо больше (p<0,001), чем в соответствующих по полу здоровых мужчин и женщин. Мышечная масса и костная масса тела по Матейко у мужчин и женщин, больных НАЖБП, оказалась статистически значимо меньше (p<0,05), чем в соответствующих по полу здоровых мужчин и женщин. Причем, мышечная и костная масса тела у здоровых и больных НАЖБП мужчин статистически значимо больще $(p<0,05)$, чем в соответствующих групп женщин. У мужчин и женщин, больных НАЖБП, установленные обратные сильные корреляционные связи между мышечной массой тела по Матейко и индексом массы тела. Также установлены обратные средней силы корреляционные связи между костной массой тела по Матейко и индексом массы тела. Полученные нами результаты, наряду с известным увеличением жировой массы тела при НАЖХП, показывают значительное изменение мышечной и костной массы тела в сторону уменьшения, что позволяет наметить новые потенциальные терапевтические мишени.

Ключевые слова: неалкогольная жировая болезнь печени, антропометрия, компонентный состав массы тела, корреляционные связи. 